\title{
Sensory tricks for isolated speech-induced lingual dystonia
}

\author{
Yasushi Shimo, ${ }^{1}$ Kazutaka Nishina, ${ }^{2}$ Taku Hatano, ${ }^{1}$ Nobutaka Hattori ${ }^{1}$
}

${ }^{1}$ Department of Neurology, Juntendo University, School of Medicine, Tokyo, Japan ${ }^{2}$ Department of Neurology and Neurological Science, Graduate School, Tokyo Medical and Dental University, Tokyo, Japan

\section{Correspondence to}

Dr Yasushi Shimo

yshimo@juntendo.ac.jp

Accepted 11 February 2015

\section{CrossMark}

\begin{tabular}{l}
\hline To cite: Shimo Y, Nishina K, \\
Hatano T, et al. BMJ Case \\
Rep Published online: \\
[please include Day Month \\
Year] doi:10.1136/bcr-2014- \\
208272 \\
\hline
\end{tabular}

\section{DESCRIPTION}

A 49-year-old woman with no medical history started to show difficulty in speaking 1 year earlier. She was not taking any antipsychotics. Except for difficulty in speaking, her neurological examination results were normal. Her brain MRI was unremarkable and no causative abnormality was found in her blood test, including copper and ceruloplasmin levels and thyroid parameters. A neuropsychiatric consultation revealed no depression or psychiatric problem. The patient eventually noticed the dramatic amelioration of her symptoms when chewing gum or pressing her neck (video 1). These could have been acting as sensory tricks for her isolated speech-induced lingual dystonia. ${ }^{1}$ There was no history of orofacial injury or recent viral infection that could have caused secondary lingual dystonia. Trihexyphenidyl (up to $8 \mathrm{mg} /$ day) or diazepam (up to $4 \mathrm{mg} /$ day) had no benefit and induced severe

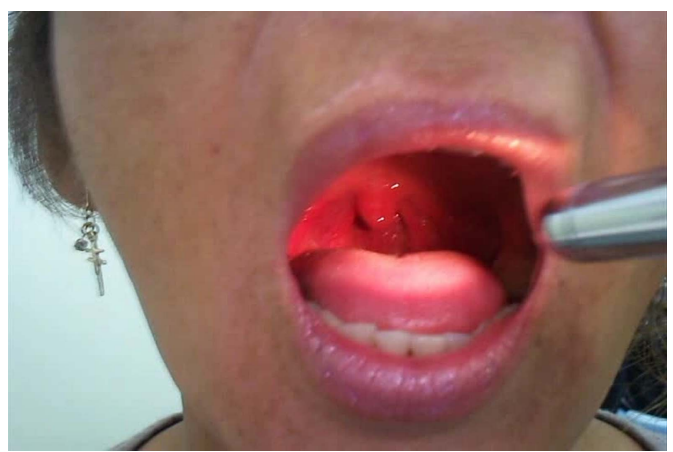

Video 1 The patient narrated a Japanese proverb. There was no involuntary movement of her tongue at rest. When she chewed gum or pressed her neck with her hands, she spoke fluently. dry mouth or sleepiness. We also tried baclofen starting at $5 \mathrm{mg} /$ day, however, the patient reported sleepiness at that dose; it was stopped. We applied these drugs separately. To rule out dopa-responsive dystonia (DYT5) and Parkinson's disease, we attempted levodopa/carbidopa treatment (up to $300 \mathrm{mg}$ ), but with no benefit.

In this rare type of focal dystonia, medical refractory symptoms can be improved by sensory tricks, and sensory tricks for idiopathic focal dystonia are helpful in differentiating this condition from psychogenic movement disorder. ${ }^{2}$

\section{Learning points}

Isolated speech-induced lingual dystonia is a rare condition.

- Medically refractory focal dystonia limit patient's daily life.

- Sensory tricks are helpful in diagnosing and alleviating the symptoms.

Contributors YS drafted the paper, designed and conducted the study, and conducted data collection. $\mathrm{KN}$ and TH conducted data collection. NH designed the study.

\section{Competing interests None.}

Patient consent Obtained.

Provenance and peer review Not commissioned; externally peer reviewed.

\section{REFERENCES}

1 Felicio AC, Godeiro C Jr, Moriyama TS, et al. Speech-induced lingual dystonia. Arq Neuropsiquiatr 2010;68:653-5.

2 Fahn S, Jankovic J, Hallett M. Principles and practice of movement disorders. 2nd edn. Elsevier, 2011.

\footnotetext{
Copyright 2015 BMJ Publishing Group. All rights reserved. For permission to reuse any of this content visit http://group.bmj.com/group/rights-licensing/permissions.

BMJ Case Report Fellows may re-use this article for personal use and teaching without any further permission.

Become a Fellow of BMJ Case Reports today and you can:

- Submit as many cases as you like

- Enjoy fast sympathetic peer review and rapid publication of accepted articles

- Access all the published articles

- Re-use any of the published material for personal use and teaching without further permission

For information on Institutional Fellowships contact consortiasales@bmjgroup.com

Visit casereports.bmj.com for more articles like this and to become a Fellow
} 